\title{
Novel Coronavirus (COVID-19) Knowledge and Perceptions: A Survey of Healthcare Workers
}

Akshaya Srikanth Bhagavathula ${ }^{1}$, Wafa Ali Aldhaleei ${ }^{2}$, Jamal Rahmani ${ }^{3}$, Mohammadjavad Ashrafi Mahabadi ${ }^{4}$, Deepak Kumar Bandari ${ }^{5}$

${ }^{1,5} \mathrm{Ph} . \mathrm{D}$ student, Institute of Public Health, College of Medicine and Health Sciences, United Arab Emirates University, Al Ain, UAE

${ }^{2}$ Gastroenterology Fellow, Department of Gastroenterology, Sheikh Shakbout Medical City, Abu Dhabi, UAE

${ }^{3} \mathrm{Ph} . \mathrm{D}$ student, Department of Community Nutrition, Faculty of Nutrition and Food Technology, National Nutrition and Food Technology Research Institute, Student Research Committee, Shahid Beheshti University of Medical Sciences, Tehran, Iran

${ }^{4}$ Medical student, Iran University of Medical Sciences, Tehran, Iran

${ }^{5}$ Department of Clinical Pharmacy, Vagdeevi College of Pharmacy, Warangal, Telangana, India

\section{Authors' email:}

Akshaya Bhagavathula: akshaypharmd@ gmail.com

Wafa Ali Aldhaleei: wafa.ali.aldhaleei@gmail.com

Jamal Rahmani: jrahmani@sbmu.ac.ir

Mohmmadjavad Mahabadi: mjamahabadi@gmail.com

Deepak Bandari: laxmideepak.pharma@gmail.com

Corresponding author

Dr. Akshaya Srikanth Bhagavathula, PharmD, PhD student,

Institute of Public Health,

College of Medicine and Health Sciences,

UAE University, Al Ain, UAE

Email: akshaypharmd@gmail.com

Phone: +971-543226187 
medRxiv preprint doi: https://doi.org/10.1101/2020.03.09.20033381; this version posted March 16, 2020. The copyright holder for this preprint (which was not certified by peer review) is the author/funder, who has granted medRxiv a license to display the preprint in perpetuity.

It is made available under a CC-BY-NC-ND 4.0 International license .

\begin{abstract}
Background: During the first week of March, the surge of coronavirus disease 2019 (COVID-19) cases reached over 100 countries with more than 100,000 cases. Healthcare authorities have already initiated awareness and preparedness activities beyond borders. A poor understanding of the disease among healthcare workers (HCWs) may result in delayed treatment and the rapid spread of infection. This study aimed to investigate the knowledge and perceptions of HCWs about COVID-19.
\end{abstract}

Methods: A cross-sectional, web-based study was conducted among HCWs about COVID19 during the first week of March 2020. A 23-item survey instrument was developed and distributed randomly to HCWs using social media; it required 5 minutes to complete. A chisquare test was used to investigate the level of association among variables at the significance level of $p<0.05$.

Results: Of 529 participants, a total of $453 \mathrm{HCWs}$ completed the survey (response rate: $85.6 \%) ; 51.6 \%$ were males, $32.1 \%$ were aged $25-34$ years, and most were doctors $(30.2 \%)$ and medical students (29.6\%). Regarding COVID-19, most of the participants used social media to obtain information (61\%), and a significant proportion of HCWs had poor knowledge of its transmission (61\%) and symptom onset $(63.6 \%)$ and showed positive perceptions of COVID-19 prevention and control. Factors such as age and profession were associated with inadequate knowledge and poor perception of COVID-19.

Conclusion: As the global threat of COVID-19 continues to emerge, it is critical to improve the knowledge and perceptions of HCWs. Educational interventions are urgently needed to reach $\mathrm{HCW}$ seyond borders, and further studies are warranted.

Keywords: Coronavirus, outbreak, COVID-19, knowledge, perceptions, healthcare, questionnaire. 
medRxiv preprint doi: https://doi.org/10.1101/2020.03.09.20033381; this version posted March 16, 2020. The copyright holder for this preprint (which was not certified by peer review) is the author/funder, who has granted medRxiv a license to display the preprint in perpetuity.

It is made available under a CC-BY-NC-ND 4.0 International license .

\section{Introduction}

Coronavirus $(\mathrm{CoV})$ infections are emerging respiratory viruses and are known to cause illness ranging from the common cold to severe acute respiratory syndrome (SARS) [1]. CoV is a zoonotic pathogen that can be transmitted via animal-to-human and human-to-human interaction [2]. Multiple epidemic outbreaks occurred during 2002 (SARS), with 800 deaths, and 2012 (Middle East Respiratory Syndrome: MERS-CoV), with 860 deaths [2,3]. Approximately eight years after the MERS-CoV epidemic, the current outbreak of novel coronavirus (COVID-19) in Wuhan City, Hubei Province, China, has emerged as a global outbreak and significant public health issue [4]. On 30 January 2020, the World Health Organization (WHO) declared COVID-19 a public health emergency of international concern (PHEIC) [5]. Astonishingly, in the first week of March, a devastating number of new cases were reported globally, and COVID-19 emerged as a pandemic. As of 12 March 2020, more than 125,000 confirmed cases across 118 countries and more than 4600 deaths had been reported [6].

COVID-19 is spread by human-to-human transmission through droplet, feco-oral, and direct contact and has an incubation period of 2-14 days [6]. To date, no antiviral treatment or vaccine has been explicitly recommended for COVID-19. Therefore, applying preventive measures to control COVID-19 infection is the most critical intervention. Healthcare workers (HCWs) are the primary sector in contact with patients and are an important source of exposure to infected cases in healthcare settings; thus, HCWs are expected to be at high risk of infection. By the end of January, the WHO and Centers for Disease Control and Prevention (CDC) had published recommendations for the prevention and control of COVID19 for HCWs [8,9]. The WHO also initiated several online training sessions and materials on COVID-19 in various languages to strengthen preventive strategies, including raising awareness and training HCWs in preparedness activities [10]. In several instances, 
misunderstandings among HCWs have delayed controlling efforts to provide necessary treatment [11], led to the rapid spread of infection in hospitals [12,13], and put patients' lives at risk. In this regard, the COVID-19 epidemic offers a unique opportunity to investigate the level of knowledge and perceptions of HCWs during this global health crisis. In addition, we aim to explore the role of different information sources in shaping HCWs' knowledge and perceptions of COVID-19 during this peak period.

\section{Methods}

A prospective Web-based cross-sectional study was conducted using a survey instrument to obtain responses from HCWs globally during the first week of March 2020.

A 23-item survey instrument was developed using WHO course materials on emerging respiratory viruses, including COVID-19 [14]. The survey covered the domains of HCW characteristics, awareness, information sources, knowledge and perceptions related to COVID-19. The developed draft survey instrument was distributed to ten randomly selected faculty members to assess its readability and validity before pretesting among 20 randomly selected HCWs for clarity, relevance, and acceptability. Refinements were made as required to facilitate better comprehension and to organize the questions before the final survey was distributed to the study population.

\section{Content of the study tool}

The survey instrument comprised 23 closed-ended questions and took approximately 3 minutes to complete. The 23-item questionnaire was divided into three parts, including participant characteristics (3 items), awareness of COVID-19 (2 items), source of information (4 statements/4-point Likert scale), knowledge about symptoms of COVID-19-affected patients ( 2 items), different modes of transmission ( 2 items), precautions and risk prevention (3 items) and perceptions of COVID-19 (7 items/true or false questions) [Supplementary file 
medRxiv preprint doi: https://doi.org/10.1101/2020.03.09.20033381; this version posted March 16, 2020. The copyright holder for this preprint (which was not certified by peer review) is the author/funder, who has granted medRxiv a license to display the preprint in perpetuity.

It is made available under a CC-BY-NC-ND 4.0 International license .

1]. Sufficient time was given to participants to read, comprehend, and answer all the questions.

\section{Ethical considerations}

Confidentiality of the study participants' information was maintained throughout the study by making the participants' information anonymous and asking the participants to provide honest answers. Eligible HCWs' participation in this survey was voluntary and was not compensated. Informed consent was obtained from each participant prior to participation. The study was performed following the Helsinki Declaration as revised in 2013. The study was conducted following the Checklist for Reporting Results of Internet E-Surveys (CHERRIES) guidelines [15] [Supplementary file 2].

\section{Data analysis}

The obtained data were coded, validated, and analyzed using SPSS version 24 (IBM, Armonk, NY, USA). Descriptive analysis was applied to calculate the frequencies and proportions. The chi-square test was used to investigate the level of association among variables. A $p$-value of less than 0.05 was considered statistically significant.

\section{Results}

A total of 529 HCWs participated, 453 of whom completed the study questionnaire $(85.6 \%$ response rate), including 234 (51.6\%) men and 219 (48.3\%) women; most of the participants were below 44 years of age $(82.4 \%)$. The majority of participants were doctors $(n=137$, $30.2 \%)$ or medical students $(n=134,29.6 \%)$ and were from Asia $(68 \%)$. Table 1 shows the sociodemographic characteristics of the participants. Almost all participants agreed that they had heard about COVID-19 (97.8\%), but only $44.1 \%$ of them had the opportunity to attend lectures/discussions about COVID-19. 
medRxiv preprint doi: https://doi.org/10.1101/2020.03.09.20033381; this version posted March 16, 2020. The copyright holder for this preprint (which was not certified by peer review) is the author/funder, who has granted medRxiv a license to display the preprint in perpetuity.

It is made available under a CC-BY-NC-ND 4.0 International license .

\section{Source of information}

When we asked about the participants' source for reliable information about COVID-19, the primary sources of information about COVID-19 were official government websites and social media (Figure 1). Approximately $30 \%$ of the participants reported that they used news media (TV/video, magazines, newspapers, and radio) and social media (Facebook, Twitter, Whatsapp, YouTube, Instagram, Snapchat) to obtain information about COVID-19. Moreover, nearly $40 \%$ of the participants sometimes discussed COVID-19-related topics with family and friends.

\section{Knowledge about COVID-19}

Table 2 shows the knowledge about COVID-19 among HCWs. We identified significant knowledge gaps between doctors and other HCWs. For instance, approximately two-thirds of doctors and half of allied health workers thought that the origin of COVID-19 was bats (65.7\% vs. $55.7 \%, p<0.05)$. A high majority of the HCWs $(85.6 \%)$ agreed that maintaining hand hygiene, covering the nose and mouth while coughing, and avoiding sick patients could help to prevent COVID-19 transmission. A majority of the doctors agreed that COVID-19 could lead to pneumonia, respiratory failure, and death $(84 \%, p<0.05)$ and that supportive care is the only treatment option that is currently available $(83.2 \%, p<0.05)$. However, the participants' knowledge about questions related to the mode of transmission and incubation period of COVID-19 was poor $(p<0.05)$.

\section{Perceptions about COVID-19}

Over $78 \%$ of the HCWs exhibited a positive perception of COVID-19. A high majority of the HCWs knew that sick patients should share their recent travel history (92.7\%), that flu vaccination is not sufficient to prevent COVID-19 (90.7\%), and that COVID-19 is not fatal (88.5\%). In addition, $87 \%$ felt that washing hands with soap and water could help to prevent 
medRxiv preprint doi: https://doi.org/10.1101/2020.03.09.20033381; this version posted March 16, 2020. The copyright holder for this preprint (which was not certified by peer review) is the author/funder, who has granted medRxiv a license to display the preprint in perpetuity.

It is made available under a CC-BY-NC-ND 4.0 International license .

COVID-19 transmission; $84.3 \%$ knew that symptoms appear in 2-14 days; and $85.6 \%$ agreed that all equipment used in wet markets should be cleaned every day. However, approximately $20 \%$ of HCWs were not clear about eating well-cooked meat during the outbreak [Table 3].

Items related to COVID-19-related perceptions among HCWs in the study were analyzed separately using the chi-square test to examine their association with age and sex and across different categories of people [Table 4].

Nearly $90 \%$ of the youngest participants ( $<25$ years) and $92 \%$ of the doctors believed that the symptoms of COVID-19 appeared as early as 2 to 14 days; the differences among the respondent groups were statistically significant $(p<0.05)$. Moreover, a significant proportion of the doctors perceived eating well-cooked/handled meat to be safe $(83.2 \%)(p<0.05)$. Medical students were found to have the perception that flu vaccination is not sufficient to prevent COVID-19 transmission $(88 \%, p<0.05)$. A large number of allied health workers incorrectly believed that it is not safe to eat well-processed meat during the COVID-19 outbreak $(25.3 \%, p<0.05)$, that COVID-19 is fatal $(21.5 \%)$, that there is a delay in symptoms $(19.8 \%)$, and that flu vaccination is sufficient $(19.8 \% ; p<0.05)$ compared with other participants in the respective groups.

\section{Discussion}

Currently, COVID-19 is a global topic of discussion in the media and among the public, especially among HCWs and patients. With the currently mounting COVID-19 transmission raising tensions for everyone, including health officials and health systems, an important question arises regarding how we manage information to help frontline HCWs in times of public health crisis. For this reason, we investigated HCWs' knowledge and perceptions of the prevention and control of COVID-19 during a global epidemic. 
medRxiv preprint doi: https://doi.org/10.1101/2020.03.09.20033381; this version posted March 16, 2020. The copyright holder for this preprint

Knowledge and perceptions of COVID-19 varied across different categories of HCWs. Our study revealed that HCWs have insufficient knowledge about COVID-19 but showed positive perceptions of the prevention of COVID-19 transmission. We also found that more than $33 \%$ of the HCWs used official government websites as a primary source of information about COVID-19. This indicates that the COVID-19-related updates posted online by official government health authorities had positive implications for improving HCWs' knowledge levels. Relying on authentic sources is a key factor in believing transparent information about the emerging COVID-19 infection and is essential for HCWs' preparedness and response. However, a finding of considerable concern is that $60 \%$ of HCWs used social media as a source of information. Currently, the vast diversity of information available through the Internet, including unverified malicious information, can spread quickly and can misguide HCWs. In particular, health authorities and scientists have warned that widespread misinformation about COVID-19 is a serious concern causing xenophobia worldwide $[4,16$ 19]. In this regard, HCWs should carefully evaluate COVID-19-related information and should use scientific and authentic content as information sources.

The findings of this study suggest significant knowledge gaps between the amount of information available about COVID-19 and the depth of knowledge among HCWs, particularly about the mode of transmission and incubation period of COVID-19. Additionally, many allied health workers had inaccurate knowledge that COVID-19 can be treated with antivirals and that there is a vaccine available. This is unfortunate because the surge of COVID-19 is globally devastating, and a large number of resources are provided by healthcare authorities to educate HCWs and improve their knowledge about COVID-19. Therefore, our findings were disappointing. Greater encouragement from health authorities is needed to assimilate COVID-19-related knowledge among HCWs, including doctors. 
medRxiv preprint doi: https://doi.org/10.1101/2020.03.09.20033381; this version posted March 16, 2020. The copyright holder for this preprint (which was not certified by peer review) is the author/funder, who has granted medRxiv a license to display the preprint in perpetuity.

It is made available under a CC-BY-NC-ND 4.0 International license .

Generally, most participants had a positive perception of the prevention and control of COVID-19. However, discrepancies were identified in the perceptions of different categories of HCWs. For instance, only half (52\%) of the HCWs aged 45-65 years believed that the symptoms of COVID-19 appeared as early as 2 to 14 days $(p<0.05)$, and more than a quarter of the medical students thought that eating meat during the outbreak was unsafe. Approximately $20 \%$ of allied health workers believed that the flu vaccine is sufficient for COVID-19 prevention. Finally, a vast majority of HCWs strongly agreed that maintaining hygiene activities, reporting recent travel history when individuals are sick, and cleaning the equipment used in wet markets are strongly recommended.

\section{Limitations}

We used WHO training material for the detection, prevention, response, and control of COVID-19 to develop a validated questionnaire. The developed questionnaire was pilot tested, and open-ended questions were limited to reduce information bias.

However, this study has some limitations that should be considered. This is a cross-sectional study conducted online among HCWs during alarming cases reported globally in the first week of March 2020. In addition, the data presented in this study are self-reported and partly dependent on the participants' honesty and recall ability; thus, they may be subject to recall bias. Finally, due to the four-week closure of higher educational institutions in the UAE during the COVID-19 outbreak [16], the institutional review board was not approached. Despite these limitations, our findings provide valuable information about the knowledge and perceptions of HCWs during a peak period of COVID-19.

\section{Conclusion}

We identified a significant gap in the source of information, poor knowledge levels, and discrepancies in perceptions of COVID-19 among our study participants. As the global threat 
medRxiv preprint doi: https://doi.org/10.1101/2020.03.09.20033381; this version posted March 16, 2020. The copyright holder for this preprint (which was not certified by peer review) is the author/funder, who has granted medRxiv a license to display the preprint in perpetuity.

It is made available under a CC-BY-NC-ND 4.0 International license .

of COVID-19 continues to emerge, greater efforts through educational campaigns that target HCWs and the wider population beyond borders are urgently needed.

Acknowledgment: We thank all the study participants for their voluntary participation and for providing essential information.

\section{Authors' contributions}

ASB designed the study, developed the questionnaire, collected the data, analyzed the data, and prepared the manuscript. WAA designed the questionnaire, conducted the pilot test, and conducted the literature review. MMJ and JR distributed the questionnaire and filtered and analyzed the data. All authors read and approved the final manuscript.

Funding: No source of funding

\section{Available data and materials}

All materials are attached as supplementary materials, and information related to the study is in the manuscript.

Consent for publication: Not applicable.

Competing interests: The authors declare that they have no competing interests.

\section{References}

1. Yin Y, Wunderink RG. MERS, SARS and other coronaviruses as causes of pneumonia. Respirology 2018;23(2):130-137.

2. Li Q, Guan X, Wu P, Wang X, Zhou L, Tong Y, Ren R, Leung KS, Lau EH, Wong JY, Xing $X$. Early transmission dynamics in Wuhan, China, of novel coronavirus-infected pneumonia. New Engl J Medi. 2020 Jan 29. Doi: 10.1056/NEJMoa2001316.

3. Bhagavathula AS, Shehab A. The story of mysterious pneumonia and the response to deadly novel coronavirus (2019-nCoV): So far!. Emirates Med J 2020;1:7-10.

4. Lai CC, Shih TP, Ko WC, Tang HJ, Hsueh PR. Severe acute respiratory syndrome coronavirus 2 (SARS-CoV-2) and corona virus disease-2019 (COVID-19): the epidemic and the challenges. Int J Antimicrob Agent. 2020:105924. Doi:10.1016/j.ijantimicag.2020.105924.

5. Eurosurveillance Editorial Team. Note from the editors: World Health Organization declares novel coronavirus (2019-nCoV) sixth public health emergency of international concern. Euro Surveill. 2020 Feb;25(5):200131e. 
medRxiv preprint doi: https://doi.org/10.1101/2020.03.09.20033381; this version posted March 16, 2020. The copyright holder for this preprint (which was not certified by peer review) is the author/funder, who has granted medRxiv a license to display the preprint in perpetuity.

It is made available under a CC-BY-NC-ND 4.0 International license .

6. World Health Organization. Novel coronavirus (COVID-19) situation. Available online: https:// https://experience.arcgis.com/experience/685d0ace521648f8a5beeeee1b9125cd (Accessed on 13 March 2020).

7. Backer JA, Klinkenberg D, Wallinga J. Incubation period of 2019 novel coronavirus (2019-nCoV) infections among travellers from Wuhan, China, 20-28 January 2020. Euro Surveill. 2020;25(5): pii=2000062.

8. World Health Organization. Infection prevention and control during health care when novel coronavirus ( $\mathrm{nCoV}$ ) infection is suspected: interim guidance, January 2020. World Health Organization; 2020. Available: https://www.who.int/publications-detail/infectionprevention-and-control-during-health-care-when-novel-coronavirus-(ncov)-infection-issuspected-20200125 (Accessed on 12 February 2020).

9. Centers for disease control and prevention. Update and interim guidelines on outbreak of 2019 Novel coronavirus (2019-nCoV). Available online: https://emergency.cdc.gov/han/han00427.asp. (Accessed on 12 February 2020).

10. World health organization. Responding to COVID-19: Real-time training for the coronavirus disease outbreak. Available online: https://openwho.org/channels/covid-19. (Accessed on 1 February 2020).

11. Hoffman SJ, Silverberg SL. Delays in Global Disease Outbreak Responses: Lessons from H1N1, Ebola, and Zika. Am J Public Health. 2018;108(3):329-333.

12. Selvaraj SA, Lee KE, Harrell M, Ivanov I, Allegranzi B. Infection Rates and Risk Factors for Infection Among Health Workers During Ebola and Marburg Virus Outbreaks: A Systematic Review. J Infect Dis. 2018;218(supp1_5):S679-S689

13. McCloskey B, Heymann DL. SARS to novel coronavirus-old lessons and new lessons. Epidemiol Infect. 2020;148:e22

14. World health organization. Emerging respiratory viruses, including COVID-19: methods for detection, prevention, response, and control. Available online: https://openwho.org/courses/introduction-to-ncov (Accessed on 1 February 2020).

15. Eysenbach G. Improving the quality of Web surveys: the Checklist for Reporting Results of Internet E-Surveys (CHERRIES). J Med Internet Res. 2004 Sep 29;6(3):e34.

16. Thomas Z. Misinformation on coronavirus causing 'infodemic'. https://www.bbc.com/news/technology-51497800 (Accessed 09 March 2020)

17. Shimizu K. 2019-nCoV, fake news, and racism. Lancet. 2020;395(10225):685-6.

18. Mejova Y, Kalimeri K. Advertisers Jump on Coronavirus Bandwagon: Politics, News, and Business. arXiv preprint arXiv 2020:2003.00923.

19. Ministry of Education. Education Ministry announces early 4-week spring vacation, starting Sunday https://www.moe.gov.ae/En/MediaCenter/News/pages/SpringVacation.aspx (Accessed 28 February 2020). 
Tables 1: Sociodemographic characteristics of Healthcare workers' $(\mathrm{N}=453)$

\begin{tabular}{|c|c|}
\hline Characteristics & Participants (\%) \\
\hline \multicolumn{2}{|l|}{ Sex } \\
\hline Male & $234(51.6 \%)$ \\
\hline Female & $219(48.3 \%)$ \\
\hline \multicolumn{2}{|l|}{ Age } \\
\hline$<25$ & $145(31.6 \%)$ \\
\hline $25-34$ & $147(32.1 \%)$ \\
\hline $35-44$ & $86(18.7 \%)$ \\
\hline $45-54$ & $47(10.2 \%)$ \\
\hline $55-64$ & $28(6.1 \%)$ \\
\hline \multicolumn{2}{|l|}{ Occupation } \\
\hline Doctors & $137(30.2)$ \\
\hline Medical students & $134(29.6 \%)$ \\
\hline Pharmacists & $61(13.5 \%)$ \\
\hline Medical academicians & $61(13.5 \%)$ \\
\hline Nurse & $24(5.3 \%)$ \\
\hline Lab-technicians & $22(4.9 \%)$ \\
\hline Dentist & $14(3.1 \%)$ \\
\hline \multicolumn{2}{|l|}{ Location } \\
\hline Asia & $308(68 \%)$ \\
\hline Africa & $72(15.9 \%)$ \\
\hline Europe & $40(8.8 \%)$ \\
\hline North America & $11(2.4 \%)$ \\
\hline South America & $7(1.5 \%)$ \\
\hline Unspecified & $13(2.9 \%)$ \\
\hline \multicolumn{2}{|l|}{ Heard about Novel coronavirus } \\
\hline Yes & $443(97.8 \%)$ \\
\hline No & $10(2.2 \%)$ \\
\hline \multicolumn{2}{|c|}{ Attended lectures/discussions about Novel Coronavirus } \\
\hline Yes & $200(44.1 \%)$ \\
\hline No & $253(55.8 \%)$ \\
\hline
\end{tabular}


medRxiv preprint doi: https://doi.org/10.1101/2020.03.09.20033381; this version posted March 16, 2020. The copyright holder for this preprint (which was not certified by peer review) is the author/funder, who has granted medRxiv a license to display the preprint in perpetuity.

It is made available under a CC-BY-NC-ND 4.0 International license .

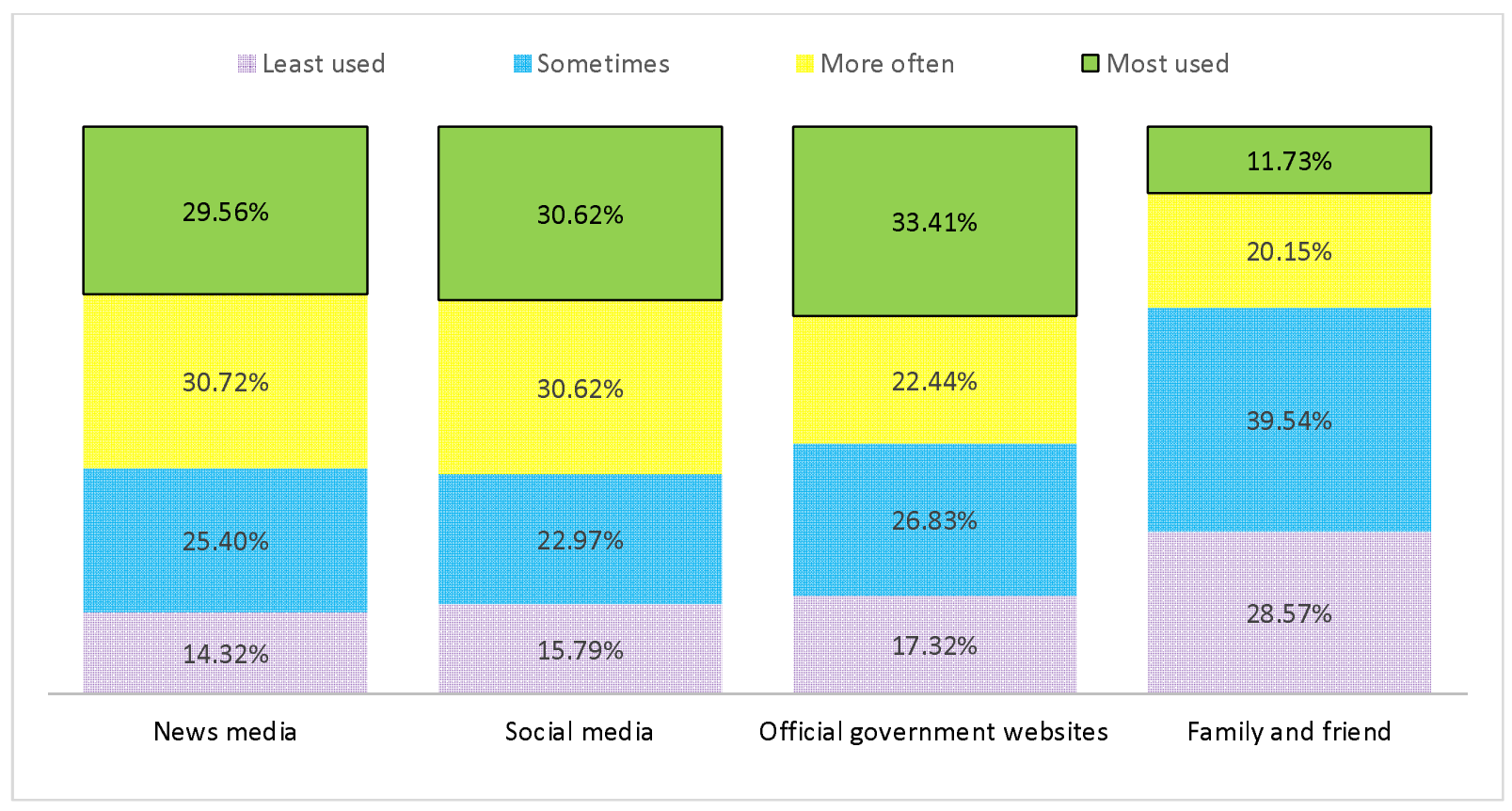

Figure 1: Source of Knowledge about Novel coronavirus 
medRxiv preprint doi: https://doi.org/10.1101/2020.03.09.20033381; this version posted March 16, 2020. The copyright holder for this preprint (which was not certified by peer review) is the author/funder, who has granted medRxiv a license to display the preprint in perpetuity.

It is made available under a CC-BY-NC-ND 4.0 International license .

Table 2: Knowledge about Novel coronavirus (COVID-19) among Healthcare workers' (N=453)

\begin{tabular}{|c|c|c|c|c|}
\hline Questions & $\begin{array}{l}\text { Doctors } \\
(n=137)\end{array}$ & $\begin{array}{c}\text { Allied health } \\
\text { workers }(n=316)\end{array}$ & $\begin{array}{l}\text { Total Correct } \\
\text { responses }\end{array}$ & P-value \\
\hline COVID-19 is thought to be originated from bats & $90(65.7 \%)$ & $176(55.7 \%)$ & $266(58.7 \%)$ & $<0.05$ \\
\hline $\begin{array}{l}\text { COVID-19 is transmitted through air, contact, fecal-oral } \\
\text { routes }\end{array}$ & $50(36.5 \%)$ & $127(40.2 \%)$ & $177(39 \%)$ & 0.46 \\
\hline $\begin{array}{l}\text { Headache, fever, cough, sore throat, and flu are } \\
\text { symptoms of COVID-19 }\end{array}$ & $\begin{array}{c}109 \\
(79.6 \%)\end{array}$ & $223(70.6 \%)$ & $332(73.2 \%)$ & $<0.05$ \\
\hline The incubation period of COVID-19 (2-14 days) & $62(45.3)$ & $103(32.6 \%)$ & $165(36.4 \%)$ & $<0.05$ \\
\hline $\begin{array}{l}\text { COVID-19 leads to pneumonia, respiratory failure, and } \\
\text { death }\end{array}$ & $115(84 \%)$ & $238(75.3 \%)$ & $353(77.9 \%)$ & $<0.05$ \\
\hline Supportive care is the current treatment for COVID-19 & $\begin{array}{c}114 \\
(83.2 \%)\end{array}$ & $193(61 \%)$ & $307(67.7 \%)$ & $<0.05$ \\
\hline $\begin{array}{l}\text { Hand hygiene, covering nose and mouth while } \\
\text { coughing, and avoiding sick contacts can help in the } \\
\text { prevention of COVID-19 transmission. }\end{array}$ & $\begin{array}{c}117 \\
(85.4 \%)\end{array}$ & $271(85.6 \%)$ & $388(85.6 \%)$ & 0.96 \\
\hline
\end{tabular}

Table 3: Perception of Healthcare workers' towards COVID-19

\begin{tabular}{|l|c|c|}
\hline \multicolumn{1}{|c|}{ Statements } & Yes & No \\
\hline COVID-19 symptoms appear in 2-14 days & $382(84.3 \%)^{*}$ & $71(15.6 \%)$ \\
\hline COVID-19 is fatal & $52(11.4 \%)$ & $401(88.5 \%)^{*}$ \\
\hline Flu vaccinated is sufficient for preventing COVID-19 & $42(9.2 \%)$ & $411(90.7 \%)^{*}$ \\
\hline $\begin{array}{l}\text { During the outbreak, eating well-cooked and safely handled } \\
\text { meat is safe }\end{array}$ & $358(78.1 \%)^{*}$ & $95(20.9 \%)$ \\
\hline $\begin{array}{l}\text { Sick patients should share their recent travel history with } \\
\text { healthcare providers }\end{array}$ & $420(92.7 \%)^{*}$ & $33(7.3 \%)$ \\
\hline $\begin{array}{l}\text { Disinfect equipment's and working area in wet markets at } \\
\text { least once a day }\end{array}$ & $388(85.6 \%)^{*}$ & $65(14.3 \%)$ \\
\hline $\begin{array}{l}\text { Washing hands with soap and water can help in prevention } \\
\text { of COVID-19 transmission }\end{array}$ & $59(13 \%)$ & $394(87 \%)^{*}$ \\
\hline
\end{tabular}

*correct answers 
medRxiv preprint doi: https://doi.org/10.1101/2020.03.09.20033381; this version posted March 16, 2020. The copyright holder for this preprint (which was not certified by peer review) is the author/funder, who has granted medRxiv a license to display the preprint in perpetuity.

It is made available under a CC-BY-NC-ND 4.0 International license .

Table 4: Association between respondents' characteristics and perceptions of COVID-19

\begin{tabular}{|c|c|c|c|c|c|c|c|c|c|c|c|}
\hline & \multicolumn{3}{|c|}{$\operatorname{Sex}(\%)$} & \multicolumn{4}{|c|}{ Age (\%) } & \multicolumn{4}{|c|}{ Profession (\%) } \\
\hline & $\begin{array}{l}\text { Male } \\
(234)\end{array}$ & $\begin{array}{l}\text { Female } \\
(219)\end{array}$ & $\begin{array}{c}\mathrm{P}- \\
\text { value }\end{array}$ & $\begin{array}{l}<25 \\
(145)\end{array}$ & $\begin{array}{l}25-44 \\
(233)\end{array}$ & $\begin{array}{c}45-65 \\
(75)\end{array}$ & $\begin{array}{c}\mathrm{P}- \\
\text { value }\end{array}$ & $\begin{array}{c}\text { Doctors } \\
(137)\end{array}$ & $\begin{array}{c}\text { Medical } \\
\text { students } \\
(134)\end{array}$ & $\begin{array}{c}\text { Others } \\
(182)\end{array}$ & $\begin{array}{c}\mathrm{P}- \\
\text { value }\end{array}$ \\
\hline \multicolumn{3}{|c|}{ COVID-19 symptoms appear in 2-14 days } & 0.85 & & & & $<0.05$ & & & & $<0.05$ \\
\hline Yes $\dagger$ & $\begin{array}{l}198 \\
(84.6) \\
\end{array}$ & $\begin{array}{l}183 \\
(83.5) \\
\end{array}$ & & $\begin{array}{l}130 \\
(89.6)\end{array}$ & $\begin{array}{l}207 \\
(88.8)\end{array}$ & $\begin{array}{l}39 \\
(52)\end{array}$ & & $126(92)$ & $\begin{array}{l}116 \\
(86.5)\end{array}$ & $\begin{array}{l}146 \\
(80.2)\end{array}$ & \\
\hline No & $36(15.3)$ & $36(16.4)$ & & $\begin{array}{l}15 \\
(10.4)\end{array}$ & $\begin{array}{l}26 \\
(11.1)\end{array}$ & $\begin{array}{l}36 \\
(48)\end{array}$ & & $11(8)$ & $18(13.5)$ & $\begin{array}{l}36 \\
(19.8)\end{array}$ & \\
\hline \multicolumn{3}{|c|}{ COVID-19 is fatal } & 0.19 & & & & 0.78 & & & & 0.31 \\
\hline Yes & $22(9.4)$ & $29(13.2)$ & & $\begin{array}{l}127 \\
(87.5)\end{array}$ & $\begin{array}{l}207 \\
(88.8)\end{array}$ & $\begin{array}{l}68 \\
(90.6) \\
\end{array}$ & & $116(84.6)$ & $\begin{array}{l}112 \\
(83.5)\end{array}$ & $\begin{array}{l}143 \\
(78.5) \\
\end{array}$ & \\
\hline No $\dagger$ & $\begin{array}{l}212 \\
(90.6)\end{array}$ & $\begin{array}{l}190 \\
(86.7)\end{array}$ & & $\begin{array}{l}18 \\
(12.5)\end{array}$ & $\begin{array}{l}26 \\
(11.1)\end{array}$ & $\begin{array}{l}7 \\
(9.4) \\
\end{array}$ & & $21(15.4)$ & $22(16.5)$ & $\begin{array}{l}39 \\
(21.5)\end{array}$ & \\
\hline \multicolumn{3}{|c|}{$\begin{array}{l}\text { Flu vaccinated is sufficient for preventing } \\
\text { COVID-19 }\end{array}$} & 0.94 & & & & 0.07 & & & & $<0.05$ \\
\hline Yes & $24(10.2)$ & $22(10.1)$ & & $\begin{array}{l}21 \\
(14.5)\end{array}$ & $\begin{array}{l}19 \\
(8.1)\end{array}$ & $\begin{array}{l}5 \\
(6.6)\end{array}$ & & $18(13.1)$ & $16(12)$ & $\begin{array}{l}36 \\
(19.8)\end{array}$ & \\
\hline No $\dagger$ & $\begin{array}{l}210 \\
(89.7)\end{array}$ & $\begin{array}{l}197 \\
(89.9)\end{array}$ & & $\begin{array}{l}124 \\
(85.5)\end{array}$ & $\begin{array}{l}214 \\
(91.9)\end{array}$ & $\begin{array}{l}70 \\
(93.4)\end{array}$ & & $119(86.9)$ & $118(88)$ & $\begin{array}{l}146 \\
(80.2)\end{array}$ & \\
\hline \multicolumn{3}{|c|}{$\begin{array}{l}\text { During the outbreak, eating well-cooked } \\
\text { and safely handled meat is safe }\end{array}$} & 0.67 & & & & 0.13 & & & & $<0.05$ \\
\hline Yes $\dagger$ & $192(82)$ & $\begin{array}{l}183 \\
(83.5) \\
\end{array}$ & & $\begin{array}{l}113 \\
(77.9)\end{array}$ & $\begin{array}{l}200 \\
(85.8)\end{array}$ & $\begin{array}{l}63 \\
(84)\end{array}$ & & $114(83.2)$ & $98(73.1)$ & $\begin{array}{l}136 \\
(74.7)\end{array}$ & \\
\hline No & $42(18)$ & $36(16.4)$ & & $\begin{array}{l}32 \\
(22) \\
\end{array}$ & $\begin{array}{l}33 \\
(14.2)\end{array}$ & $\begin{array}{l}12 \\
(16)\end{array}$ & & $23(16.8)$ & $36(26.9)$ & $\begin{array}{l}46 \\
(25.3)\end{array}$ & \\
\hline \multicolumn{3}{|c|}{$\begin{array}{l}\text { Sick patients should share their recent } \\
\text { travel history with healthcare providers }\end{array}$} & 0.84 & & & & 0.51 & & & & $<0.05$ \\
\hline Yes $\dagger$ & $\begin{array}{l}228 \\
(97.4)\end{array}$ & $\begin{array}{l}214 \\
(97.7)\end{array}$ & & $\begin{array}{l}141 \\
(97.2)\end{array}$ & $\begin{array}{l}229 \\
(98.2)\end{array}$ & $\begin{array}{l}72 \\
(96)\end{array}$ & & $131(95.6)$ & $\begin{array}{l}124 \\
(92.5)\end{array}$ & $\begin{array}{l}158 \\
(86.8)\end{array}$ & \\
\hline No & $6(2.6)$ & $5(2.3)$ & & $\begin{array}{l}4 \\
(2.8)\end{array}$ & $\begin{array}{l}4 \\
(1.8)\end{array}$ & $3(4)$ & & $6(4.4)$ & $10(7.5)$ & $\begin{array}{l}24 \\
(13.2)\end{array}$ & \\
\hline \multicolumn{3}{|c|}{$\begin{array}{l}\text { Disinfect equipment's and working area in } \\
\text { wet markets at least once a day }\end{array}$} & 0.26 & & & & 0.54 & & & & 0.41 \\
\hline Yes $\dagger$ & $\begin{array}{l}205 \\
(87.6)\end{array}$ & $\begin{array}{l}199 \\
(90.8)\end{array}$ & & $\begin{array}{l}131 \\
(90.3)\end{array}$ & $\begin{array}{l}206 \\
(88.4)\end{array}$ & $\begin{array}{l}64 \\
(85.3)\end{array}$ & & $116(84.6)$ & $\begin{array}{l}117 \\
(87.3)\end{array}$ & $\begin{array}{l}149 \\
(81.8)\end{array}$ & \\
\hline No & $29(12.4)$ & $20(9.2)$ & & $\begin{array}{l}14 \\
(9.7)\end{array}$ & $\begin{array}{l}27 \\
(11.6)\end{array}$ & $\begin{array}{l}11 \\
(14.7)\end{array}$ & & $21(15.4)$ & $17(12.7)$ & $\begin{array}{l}33 \\
(18.2)\end{array}$ & \\
\hline \multicolumn{3}{|c|}{$\begin{array}{l}\text { Washing hands with soap and water can } \\
\text { help in prevention of COVID-19 } \\
\text { transmission }\end{array}$} & 0.58 & & & & 0.24 & & & & 0.88 \\
\hline Yes $\dagger$ & $\begin{array}{l}204 \\
(87.2)\end{array}$ & $\begin{array}{l}187 \\
(85.3)\end{array}$ & & $\begin{array}{l}120 \\
(82.7)\end{array}$ & $\begin{array}{l}207 \\
(88.8)\end{array}$ & $\begin{array}{l}65 \\
(86.6)\end{array}$ & & $118(86.1)$ & $\begin{array}{l}116 \\
(86.5) \\
\end{array}$ & $\begin{array}{l}160 \\
(87.9)\end{array}$ & \\
\hline No & $30(12.8)$ & $\begin{array}{l}32 \\
(13.6 \%)\end{array}$ & & $\begin{array}{l}25 \\
(17.3)\end{array}$ & $\begin{array}{l}26 \\
(11.1)\end{array}$ & $\begin{array}{l}10 \\
(13.4)\end{array}$ & & $19(13.9)$ & $18(13.5)$ & $\begin{array}{l}22 \\
(12.1)\end{array}$ & \\
\hline
\end{tabular}

$\dagger$ Correct answers; Significant at $\mathrm{P}<0.05$ (bolded) 